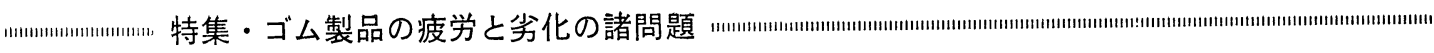

\title{
ゴム製品の疲労と劣化に関する協同 調查研究について
}

ゴム工業技術員会

第 1 特別研究委員会委員長 大 北 忠 男*

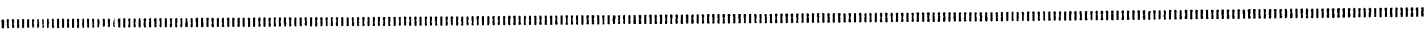

日本ゴム協会の下部組織であるゴム工業技術員会では 5 年前からゴム技術シンポジウムを年 1 回開催し，ゴム の科学および技術の進歩に寄与してきたが，これをます ます有効にするために, 特別の問題ごとに特別研究委員 会を組織し，相当の日数と費用をかけ協同調査拉よび研 究を行なうことにした。

この第 1 回として「ゴム製品の疲労と劣化に関する協 同研究」が取り上げられ，この第 1 特別研究委員会が発 足した. 委員会は下記のとおり繊維学会の代表者も参加 し, 三つの小委員会にわかれ調查研究を行子い，その結 果をまとめたものが今回の報告である.

(1) ゴム製品の疲労と劣化に関する文献集

まづ協同調查の 1 つとて1945年以降の上記に関する 文献（繊維の疲労も含め）を調查し，その題目集をまと め，また必要なものについては小題目を設け，あるいは そのまま抄訳し付け加え, 昨年12月末「ゴム製品の疲労 劣化文献集」として刊行した。

第 1 章はゴムの疲労, 変質, 破壊に関する文献題目集 および抄録集であり，福田教授が中心となり青木氏ほか
13氏およびゴム工業技術員会第35分科会（防振ゴム）関 係者が担当し，23の文献を44ページにわたり紹介してい る。

第 2 章は繊維を含む構成物の疲労に関する文献集およ び抄録集であり，繊維学会の協力を得て完成した。これ は第 2 小委員会（委員長神原周氏）の担当であるが，文 献集の分担は石川教授が長となり，繊維学会では伊藤氏 ほか27氏がまたゴム協会側では表氏ほか 8 氏およびその 関係会社ならびに大学が協力し完成した。

内容はまゔ題目集が内外にわたり 1945年以降 597件を 収め, 次いで抄録集が総説, 構造, 力学的性質, 疲労と 摩耗，試験，化学変化を伴うもの，および原料，製造方 法にわけられ，繊維だけの疲労劣化について.も詳しく88 ページにわたり述ベられている。この繊維の疲労につい ては，かかる文献集にあまり見当らないので今後重要な 参考になるものと思う．

第 3 章はゴムの老化, 耐熱, 耐オゾンなどの文献集で あり第 3 小委員会の大北が中心となり，浅尾氏ほか 16 名 およびその関係会社と研究所が協力し727件を集録した.

特別第 1 研究委員会の構成

委員長 大北思罗 第 1 小委員会 ゴムの振動疲労，変質，破壞に関す る調查研究

$$
\begin{aligned}
& \text { 委員長 福田正成 } \\
& \text { (京都工芸繊維大学: }
\end{aligned}
$$

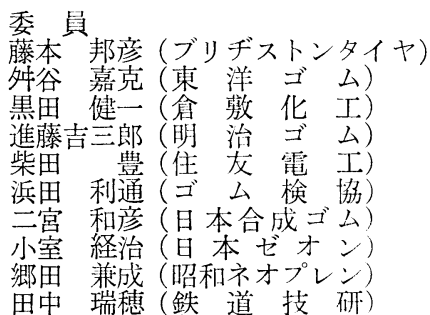

第 2 小委員会

繊維を含むゴム構成物の疲労の調査 研究

$$
\text { 委員長 神原㤟工大学) }
$$

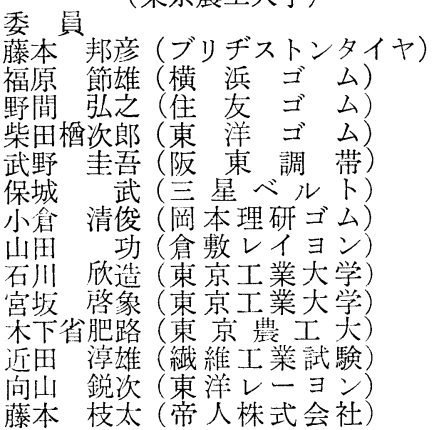

第 3 小委員会 ゴムの老化，耐熱に関守る調査研究 委員長 大北忠男

(芝浦工業大学)

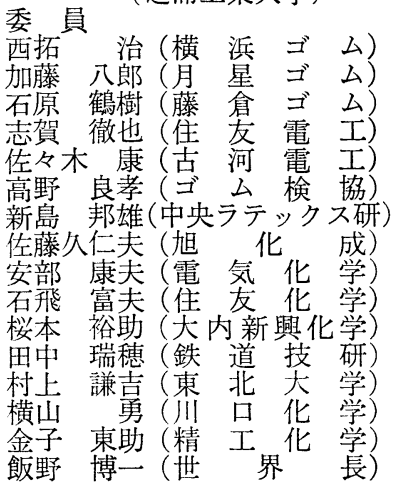


またその抄録は老化の温度係数について，ゴムの酸素吸 収とその装置, 充てん剂と老化の関係, 加硫状態との関 連，ゴム種別による差，オゾン劣化，老化防止剤，加硫 促進剤の差, オゾン劣化防止剤, 酸化劣化機構, 耐熱劣 化，光の作用などに分類した．またこれらはできるだけ 参考にしやすく有効に使用できるよう項目によっては普 通より詳しく，かつ図表を付けて抄録した。このため使 用ページ数は 170 ページとなり, ページ数では全体の半 ばを占めることとなった。

第 4 章はゴムを中心としたレオロジーに関するもので あり，これもあまり例のない集録であり，第 3 小委員会 の村上教授が中心となり，その属する東北大学でまと め, 担当者は伊藤氏ほか 9 名である. 化学レオロジーの 文献題目集とこのうち重要と思われ文献の抄録集, およ び物理レオロジーに関する文献題目集, このうち重要文 献の抄録項目は603件, 使用ページ数は66ページである.

すなわちこの編集については延べ 80 人以上のゴム技術 者が関係し, 約 2,200 の文献が集録されており, 戦後のゴ ム製品およびその材料の疲労と劣化に関する文献の集大 成である.関係者の非常な努力に感謝する次第である.

(2) 協同研究について

これについては第 1 小委員会では福田教授が委員長と なり各社手持ちの各種のゴム振動疲労試験機が共通試料 により各種の条件で振動疲労せしめ, その結果を比較し た(福田委員長報告参照).

また，第 3 小委員会では大北が委員長となり，代表的 各種ゴムの標準配合を作りこの共通試料で $50 \sim 160^{\circ} \mathrm{C}$ の 試験管引熱老化試験を行ない，また自然老化を15年間行 なうべく進行中である。かつまたその一部には第 1 小委 員会の共通試料も加え, 加熱劣化と振動疲労の相関性に ついても検討した。これらは田中委員および久留宮委員 が中心となり共同研究をとりまとめ, その結果が次の報 告である。

第 2 小委員会ではゴムと繊維の複合物に関する調查研 究の委員会 (委員長神原教授) であるが，これは多種多 様にわたりまたそれを統一する試験法もまだ確立されな いまま，共同研究は行なわずその前提としての文献の調 查研究にとどめた (次の神原委員長の報告参照).

これら共同研究の成果は, 引続いて各委員が詳しく報 告するが，その成果の一端を述べると：一一耐熱老化と
疲労破壊の間には必ずしも相関性は認められず（疲労に よる性能変化は別), 相反する結果が得られることがあ り，また振動疲労の寿命は必ずしも10\%くらいの初期ひ ずみを与えて使うほうが長くなるとは限らず，伸長では 全く逆に最小となり，かっ S B Rなどでは初期ひら゙みの 少ないほらが長寿命の結果が得られたり，またNRでは 初期引張りひずみの影響が非常に大きいが，S B Rはそ れほどでなく，したがってひずみの大きい時はNRが寿 命が長いが，低ひずみでは S B Rのほうが寿命が長くな り，かえってよい結果が得られる場合があるなどであ る.

これらの結果は今まであまり知られていなかった事実 であり，合成ゴムの出現や配合技術の進歩に関係したこ とであると思われ，ゴム工業にとってきわめて重要な結 果であり, またゴム科学にとっても非常に興味のある事 実であり，この詳しい解明によってさらに進歩がもたら されよう。

\section{(3) 感謝の言葉}

以上の共同研究は, 第 1 回目の試みとしてその初期で は完全に遂行できるかどうか相当の疑問もあったが，国 沢幹事長を中心とするゴム工業技術員会の幹事会および 主査の方々の強力なバックアップにより，また委員およ びその属する会社, 学校, 研究所の理解と協力により, かつまたこの費用支出において下述の各社, 各団体の研 究助成により完遂し，所期以上の成果を得ることができ た. 厚く感謝する次第である。

研究助成会社団体名（敬称略, 順不同）

日本ゴム工業会

日本自転車タイヤ工業会

倉敷レイヨン株式会社.

日本合成ゴム株式会社

日本ゼオン株式会社

旭化成工業株式会社

電気化学工業株式会社

昭和ネオプレン株式会社

住友化学工業株式会社

大内新興化学工業株式会社

川口化学工業株式会社

精工化学工業株式会社

（*芝浦工業大学学長代行） 